\title{
The use of titanium alloy (F136) in surgical implants
}

\author{
Silva Jr WC§, Silva MP§, Costa RH§, Souza CMP§
}

\author{
§Instituto Federal de São Paulo, São Paulo, Brazil
}

\begin{abstract}
Titanium has been widely used in the area of biomaterials, the segment of manufacture of products for rehabilitation goes through a constant evolution, because each year new techniques appear, new technologies that help in the development of biomaterials, these evolutions are mostly aimed at cost reduction, osseointegration, biocompatibility among other factors. The objective of this article is to carry out the analysis of the fixation screws of the femur prosthesis and hip prostheses, manufactured in titanium alloy ASTM 136. The use of titanium alloys in orthopedic, dental and aeronautical applications has increased in recent decades. The use of titanium in biomaterials is due to its singularities in the physiological environment and its favorable chemical and mechanical properties such as good resistance to corrosion, high degree of biocompatibility and low modulus of elasticity. For the fixation screws, analyzes of their resistance to torsion and the fracture surfaces of the tested samples were performed, for the analyzes were used Scanning Electron Microscopy (SEM) and semiquantitative analysis of the chemical elements by X-ray spectroscopy by dispersion in (EDS) and for the hip prosthesis, the fatigue test will be carried out according to ABNT NBR 7206-6. These tests aim to verify if both are able to be sold on the national market. With the tests completed, the results were compared with the standards in force. The results of the torsion tests are presented, where all samples met the quality requirements and the hip prostheses showed a stable behavior during the 10.000.000 million cycles, without failures during or after the tests.
\end{abstract}

Keywords. Prosthesis, femoral prosthesis fixation screw and Scanning Electron Microscopy.

Introduction. In Brazil, the biomaterials market was 690 million dollars in 2010, with an expectation that it will reach 2 billion in 2017 (growth of 20\%) (1). In 2011, orthopedic surgeries in Brazil reached almost 300 thousand per year, according to data from the Sistema único de Saúde - SUS reported on the Portal Brazil (2).

Biomaterials are substances or mixtures, of synthetic or natural origin, used in biological systems to restore functions compromised by degenerative processes or traumatic, in the form of implants, devices or systems (3).

Humanity, over the years, has always sought empirically in nature for materials to replace, add, or reconstruct, damaged organs and limbs of the human body (4) in the 19th century, for example, several metals have been tried for the dental implant. At that time, gold, silver and platinum were frequently used, but with failure, since these metals led to intoxication or excessive deformation. It was from the 1960s, in the 20th century, that dental implant materials underwent accelerated development, reaching the discovery that titanium had excellent mechanical properties for dental application and still being able to promote osseointegration. 
Titanium is a biomaterial commonly used in the manufacture of dental implants because it exhibits excellent chemical characteristics such as high stability in surface oxide layer (5).

The use of titanium constitutes about $0.63 \%$ of the entire earth's crust, thus being the ninth most abundant element in the earth's crust, if only metals are considered, titanium is the fourth in the list behind only aluminum, iron and magnesium (6).

The application of titanium is particularly suitable for working in corrosive environments or for applications where its low weight is essential. Because titanium has a high strength-to-weight ratio and non-magnetic properties (7).

The high interest in the use of titanium by researchers, is due to the fact that its properties are favorable, mainly due to its biocompatibility and high ductility. Titanium has half the density of $\mathrm{Ni}-\mathrm{Cr}$ and $\mathrm{Co}-\mathrm{Cr}$ alloys (8).

\section{Materials and methods.}

In this work were used: optical microscope, scanning electron microscope (SEM), Instron model 8108 fatigue testing machine and Instron torsion test, for E10000T fatigue electrodynamic tests.

The torsion test was performed according to the methodology of the ASTM F543-13 e1 Standard Specification and Test Methods for Metallic Medical Bone Screws, part of the Test method for determining the torsional properties of metallic bone screws. The tests were performed according to the internal specific instruction IE LIM $104 \mathrm{v} 05$ - Bone Screw Test, with the purpose of determining the resistance to torsion.

For each test, the part of the tip of the screw, considered the bottom part, was fixed in a pressure claw avoiding its rotation during the test. Thus, a clamping length of $(20.00+0.10) \mathrm{mm}$ and a test length of $(18.50+0.10) \mathrm{mm}$ were maintained, allowing for 5 exposed threads. The part of the screw head, considered the upper part, was fixed in a pressure claw that rotates during the test, allowing the screw to twist.

The test was carried out in a dry medium with a temperature of $(22.0+2.0){ }^{\circ} \mathrm{C}$. It was driven at a constant speed of 1 RPM. The test configuration can be seen in the Figure 1.

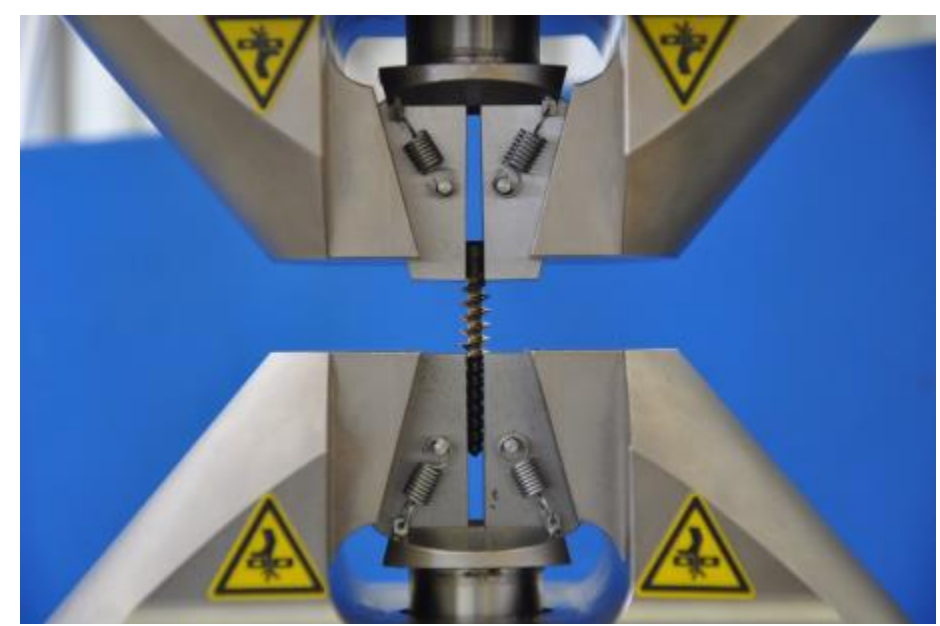

Figure 1. Screw torsion test with constant speed and top jaw closed. 
Figure 2 shows the samples of screws that were tested, manufactured with the material ASTM F136 and described as spongy, diameter $6.5 \times 45$ total thread, lot 3966H16 and reference 1463.

Figure 2. Test items before testing.

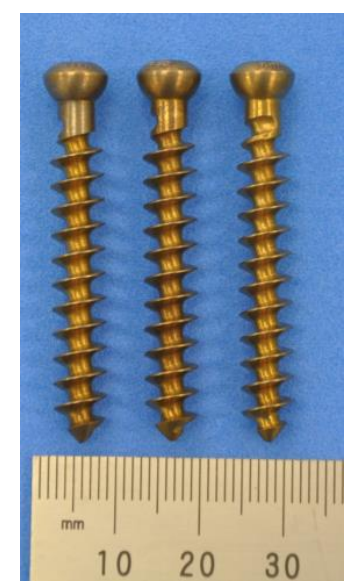

In this work, three samples of ASTM F136 Titanium screws were analyzed, table 1 shows their characteristics.

Table 1- Characteristic of the samples.

\begin{tabular}{|c|c|c|c|c|}
\hline \multirow{2}{*}{ Item } & \multicolumn{2}{|c|}{ Sample identification by the customer } & \multirow{2}{*}{$\begin{array}{c}\text { Identification of } \\
\text { test items }\end{array}$} \\
\cline { 2 - 4 } & Description & reference & lot & ED-094/17-A1a \\
\hline 01 & $\begin{array}{c}\text { Spongy Screw Ø 6,5 mm x 45 mm, rosca } \\
\text { total, Titânio ASTM F 136.1.0 }\end{array}$ & 1463 & $3966 \mathrm{H} 16$ & ED-094/17-A1b \\
\hline 02 & $\begin{array}{c}\text { Spongy Screw Ø 6,5 mm x 45 mm, rosca } \\
\text { total, Titânio ASTM F 136.1.1 }\end{array}$ & 1463 & $3966 \mathrm{H} 16$ & ED \\
\hline & $\begin{array}{c}\text { Spongy Screw Ø 6,5 mm x 45 mm, rosca } \\
\text { total, Titânio ASTM F 136.1.2 }\end{array}$ & 1463 & $3966 \mathrm{H} 16$ & ED-094/17-A1c \\
\hline
\end{tabular}

The SEM provides information quickly about the identification of the chemical elements in a sample and their morphology (9). The scanning electron microscope is commonly used in biology, chemistry, dentistry, engineering, geology, metallurgy, physics and pharmacy. One of the qualities of the SEM is its versatility for the observation and analysis of microstructural characteristics of solid objects.

The operation of the Scanning Electron Microscope (SEM) consists of using a small diameter electron beam that scans the sample surface, point after point, for several successive lines and transmits the detector's signal to a cathode screen whose scanning is synchronized perfectly with the incident beam. A system of deflection coils, the electron beam is guided so that it scans the sample surface using a rectangular mesh. The image signal is generated through the interaction of the incident beam with the sample surface, so the signal collected by the detector is used to modulate the brightness of the monitor, allowing observation (8). 
To submit the screws for analysis, it was necessary to manually saw the screws, so that the size of their body was similar to their respective heads, in order to avoid the instability of the parts, the bases of the body were sanded to give better stability.

The samples were positioned as shown in figure 3 , and fixed with a carbon ribbon, being positioned on the machine, the samples to be analyzed will be reproduced at an angle of $90^{\circ}$ on the computer, with an increase of up to $10,000 x$.

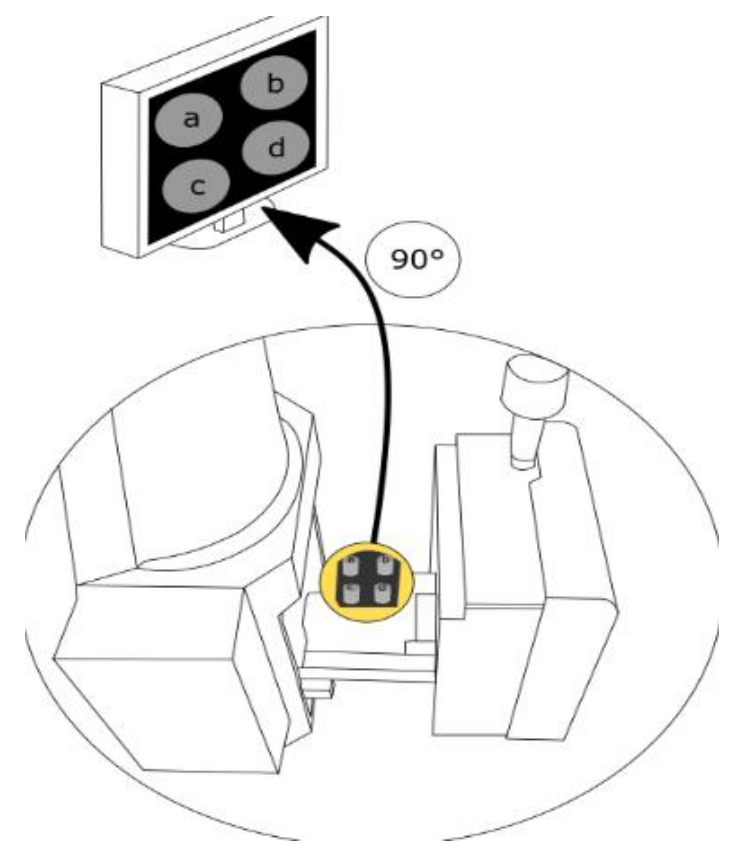

Figure 3. Scheme of the Scanning Electron Microscope (SEM) showing the positioning of the samples at $90^{\circ}$.

For this analysis of the behavior of the screw during the test, the functions of backscattered electrons (composition analysis, BSE) and secondary electrons (topographic analysis, SE) were used.

Bone tissue is a complex natural compound consisting of soft and resistant protein collagen, which has a density between 1.6 and $1.7 \mathrm{~g} / \mathrm{cm}^{3}$. Bone is an anisotropic material with mechanical properties that differ in the longitudinal and transverse directions (10).

The mechanical fatigue test was performed, following the procedures of the ABNT NBR 72066: 2013 standard. A F136 titanium prosthesis was tested, together with a modular head, the sample was placed on a machined support to be fixed on the fatigue testing machine, ultra-fast drying cement was used, a $100 \mathrm{~mm}$ acrylic tube was used diameter and $1000 \mathrm{~mm}$ high and 3 $\mathrm{mm}$ wall thickness with a lactic polyacid support (PLA) for positioning the prosthesis within the alpha and beta angles $10^{\circ}$ and $9^{\circ}$ respectively, required by the current standard.

After positioning the prosthesis, the prosthesis is embedded, as shown in Figure 4. The prosthesis was segregated for 24 hours, while the cement reaches the end of its curing process, to obtain maximum strength. 


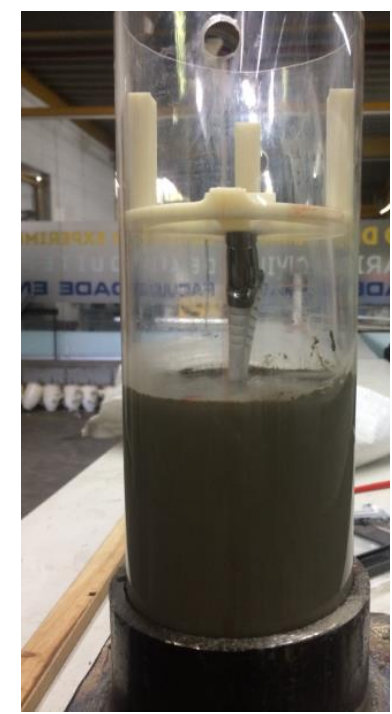

Figure 4. Prosthesis during the cement curing process.

The fatigue test was performed using the following parameters: compression load, with a frequency of $15 \mathrm{~Hz}$ with a minimum load of $-0.3 \mathrm{kN}$ and a maximum of $-3.0 \mathrm{kN}$ (compression), a ratio $\mathrm{R}=0.10$ with minimum application of 10 million cycles and a jaw displacement range of 0.477 , as can be seen in Figure 5 .

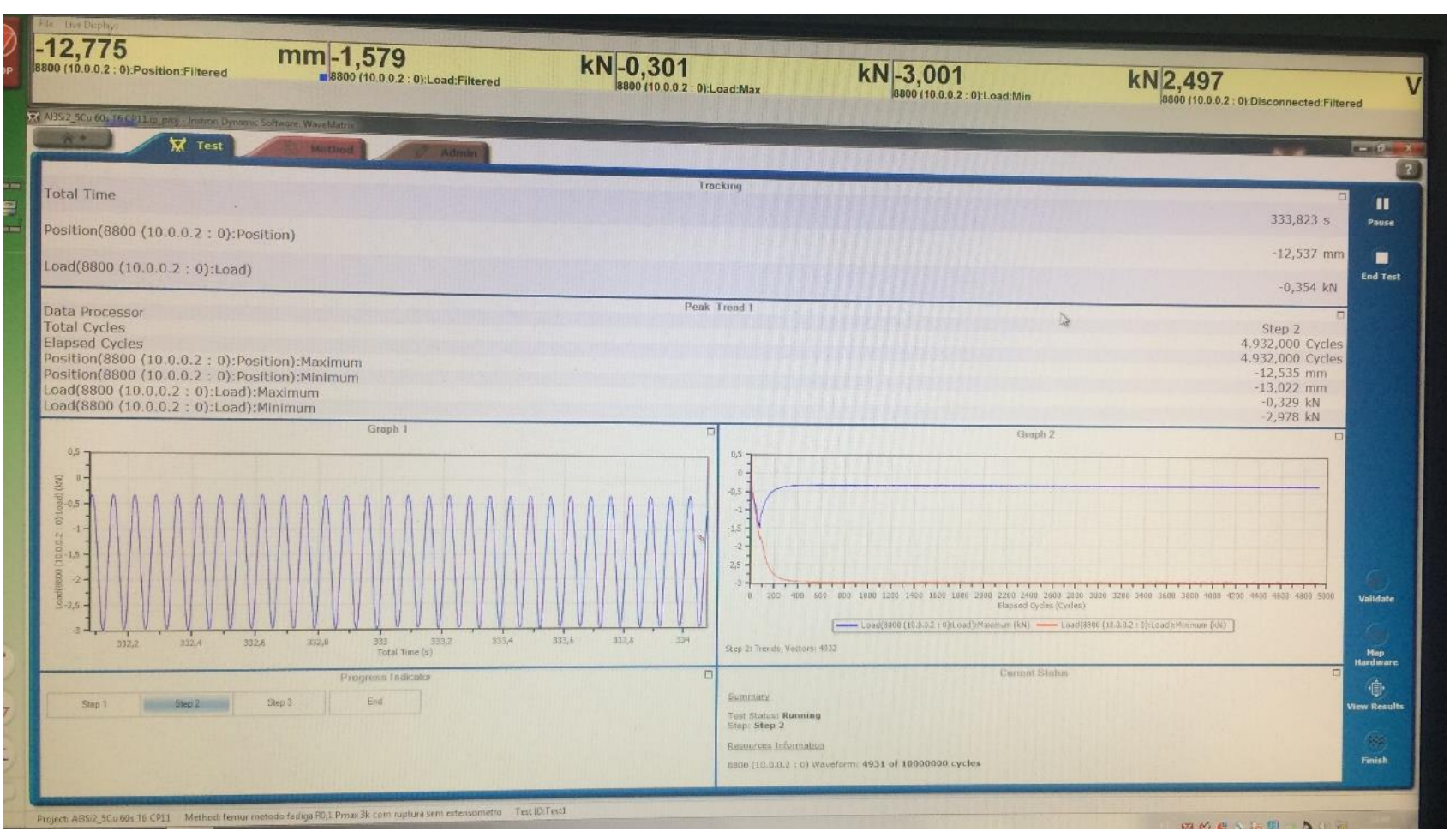

Figure 5. Monitoring via computer during rehearsal.

For the fatigue test, an Instron model 8801 fatigue test machine was used, the base was positioned on the machine, as shown in Figure 6, afterwards two hoses with $10 \mathrm{~mm}$ diameters 
were connected on the sides for saline inlet and outlet. The acrylic was filled with 1.5 liters of saline and the aquarium was filled with 7 liters of saline, with a $0.9 \%$ sodium chloride solution.

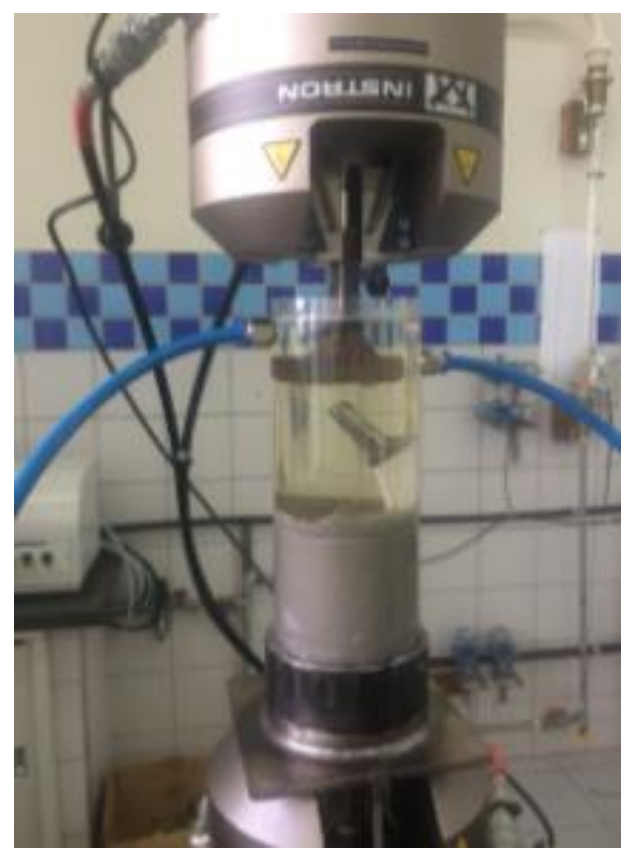

Figure 6. Positioning of the prosthesis during the fatigue test.

The typical composition of the titanium alloy used in surgical implants is shown in table 2 .

Table 2- Typical composition of titanium alloy (11).

\begin{tabular}{c|c|c}
\multicolumn{2}{c}{ Chemical requirement (ASTM F136 standard) } \\
\hline Elements & $\begin{array}{c}\text { Composition, \% } \\
\text { (mass/mass) }\end{array}$ & $\begin{array}{c}\text { tolerance below the } \\
\text { minimum or above the } \\
\text { maximum limit } \% \\
\text { (mass/mass) }\end{array}$ \\
\hline Nitrogen & 0.05 máx & 0.02 \\
\hline Carbon & 0.08 máx & 0.02 \\
\hline Hydrogen & 0.012 máx & 0.002 \\
\hline Iron & 0.25 máx & 0.1 \\
\hline Oxygen & 0.13 máx & 0.02 \\
\hline Aluminum & 5.5 a 6.5 & 0.4 \\
\hline Vanadium & 3.5 a 4.5 & 0.15 \\
\hline Titanium & $/ / /$ & $/ / / /$ \\
\hline
\end{tabular}




\section{Results.}

In the torsion tests, the fracture surfaces of the samples were analyzed and different reliefs were identified with the use of secondary electrons, as shown in figures $7 \mathrm{a}$ and $7 \mathrm{~b}$.

Analysis by X-ray spectroscopy by energy dispersion -EDS, which is qualitative and semiquantitative, were chosen areas of the fracture surfaces for these studies, figure 8 shows the result of an area.

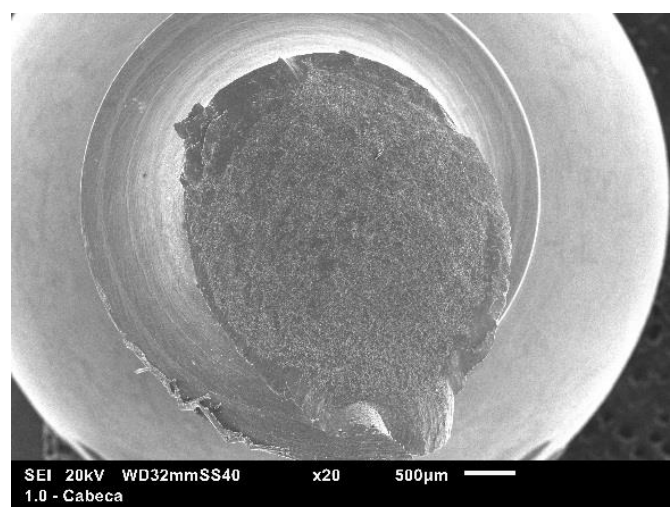

a)

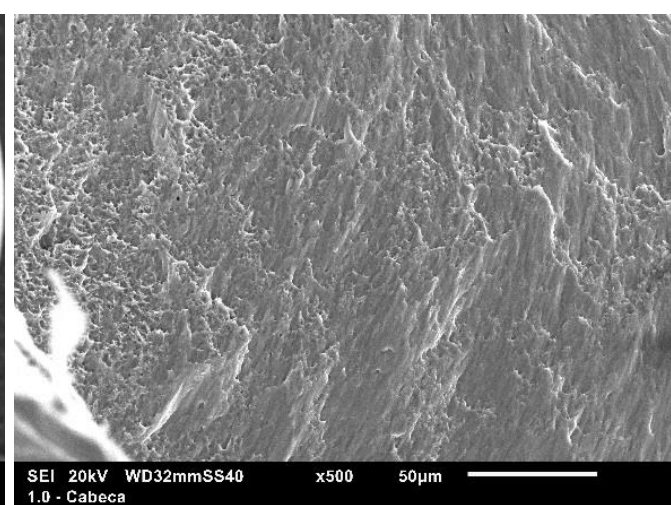

b)

Figure 7. Secondary electron images on the screw surface a) 20x b) 500x.

With the results obtained, they were compared with the ASTM F136 standard, the data can be seen in table 3.

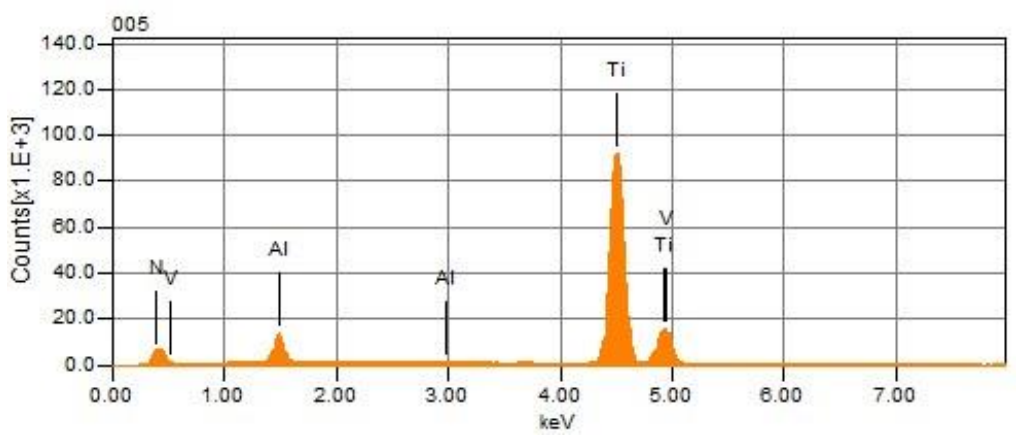

Figure 8. EDS of screw fracture surface tested for torsion.

Figure 9 shows the quantitative and qualitative analysis of inclusions for the Ti6Al4V alloy, it is verified that the quantity of inclusions are within the indicative of the standard and the types found are of the globular oxides type. 


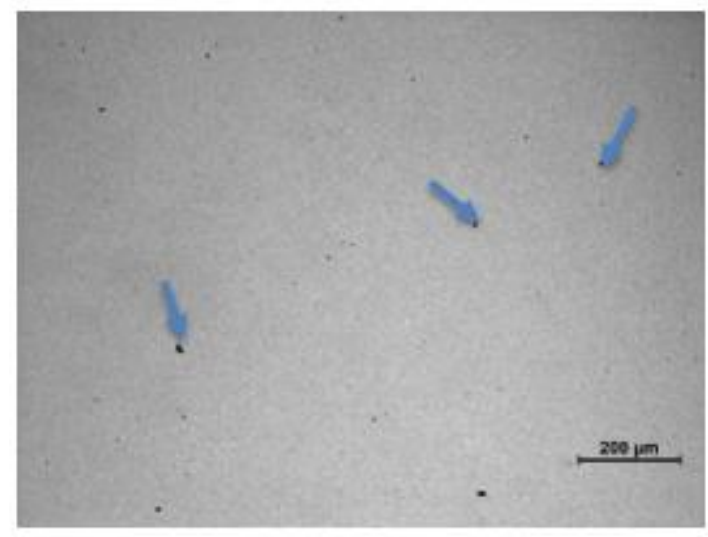

a)

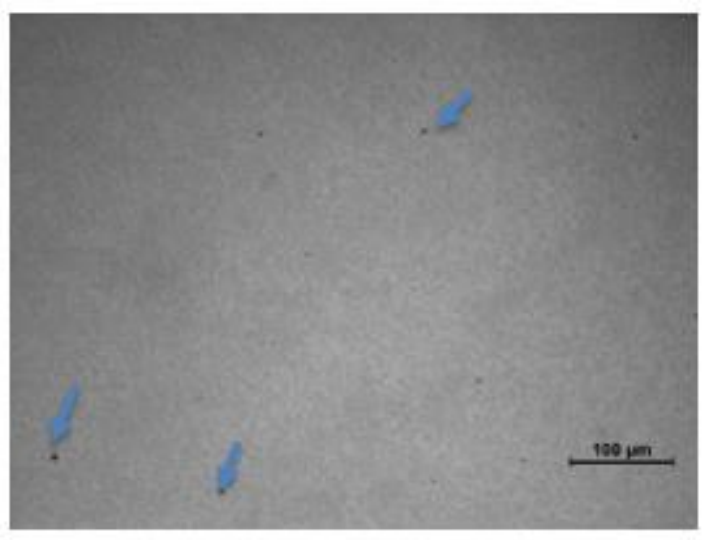

b)

Figure 9. Surface without attack for inclusion analysis a) 200x b) 100x

Table 3 - Comparative table of chemical composition.

\begin{tabular}{c|c|c|c}
\hline \multicolumn{3}{c}{ Chemical requirement (ASTM F136 standard) } & Results obtained (average) \\
\cline { 3 - 4 } Elements & Composition (\%) & Tolerance (\%) & Composition (\%) \\
\hline Nitrogen & 0,05 máx. & 0,02 & 1,38 \\
\hline Carbon & 0,08 máx. & 0,02 & 9,14 \\
\hline Hydrogen & 0,012 máx. & 0,002 & - \\
\hline Iron & 0,25 máx. & 0,1 & 0,47 \\
\hline Oxygen & 0,13 máx. & 0,02 & 1,43 \\
\hline Aluminum & 5,5 a 6,5 & 0,4 & 3,12 \\
\hline Vanadium & 3,5 a 4,5 & 0,15 & 5,04 \\
\hline Titanium & /// & $/ / /$ & 89,06 \\
\hline
\end{tabular}

In the fatigue test, the prostheses tested showed no flaws that could be seen in preliminary analysis, the deformations observed were elastic, there was no fracture or corrosion, the test lasted approximately 8 days.

In the Figure 10, it was possible to verify that the deformation of the prosthesis in the cycle to which it was submitted remained constant at $0.3 \mathrm{~mm}$. 


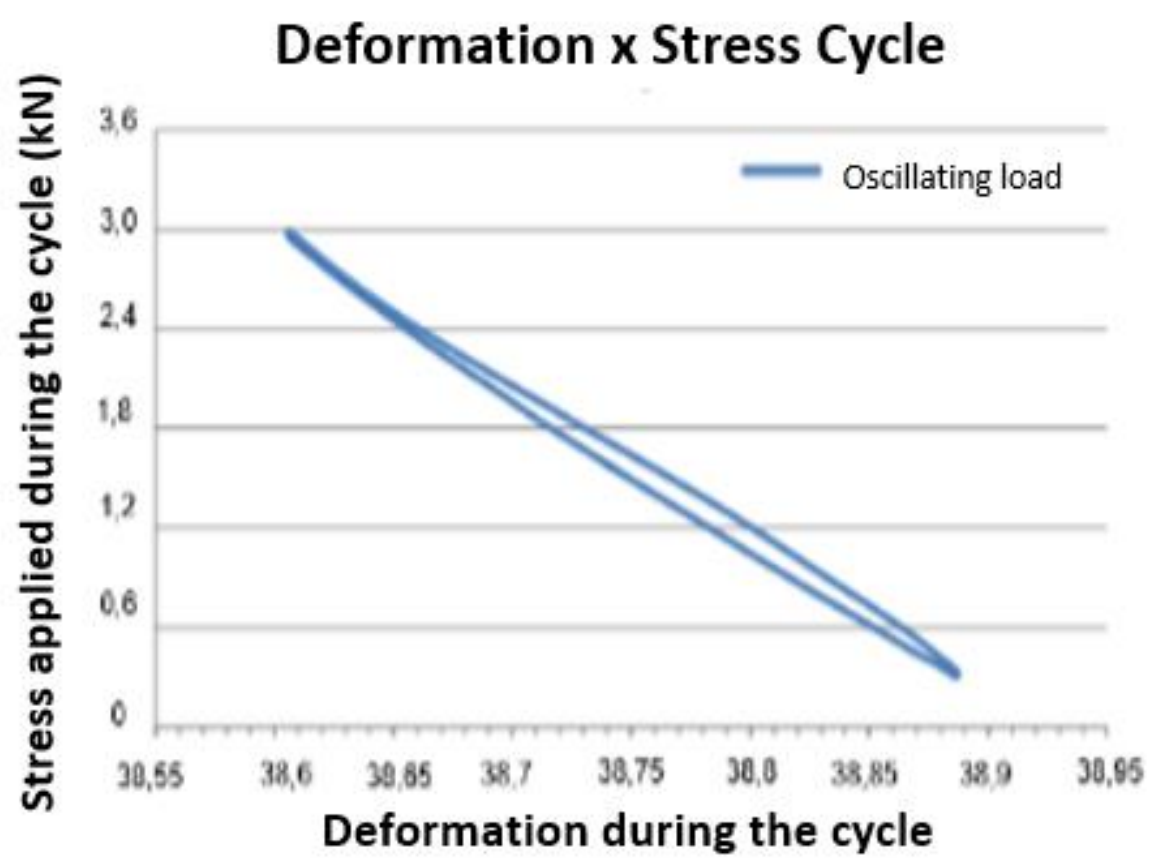

Figura 10. Load cycle chart applies to $10,087,914$ million cycles.

Conclusion. With all the tests completed and the comparisons with the standards in force that define the main characteristics of the F136 alloy applied in surgical implants, the effectiveness of the hip prosthesis was proven, so that it is possible to affirm that the hip prosthesis of the titanium alloy is in line with the standards of the new ANVISA regulations.

The screws showed torsional behavior above the requirements of the standard.

The titanium alloy presents the conditions of mechanical properties necessary for applications in prostheses and fracture healing accessories.

Future work based on the results obtained suggests the development of research that contemplate the following aspects. Checking the corrosion properties of the screws, depending on the environments in which they are involved, such as synovial fluids and blood. Perform the same scope of work with titanium alloy, which also it is used in implant screws.

Disclosure. The authors report that there are no conflicts of interest in this work.

\section{References}

(1) BENTO, Carlos Alberto da Silva. Estudo da interface ti-6Al-4V/TioO2 por microscopia eletrônica de varredura. 2000. Dissertação (Mestrado em Ciências e Engenharia de Materiais) - Universidade de São Paulo, São Paulo, 2000.

(2) Portal Brasil - http://www.brasil.gov.br/saude/2012/09/cinco-estados-recebemmutirao-de-cirurgiaortopedica, acessada em 03/04/2018. 
(3) TURRER C. L., FERREIRA F. P. M. Biomateriais em Cirurgia Craniomaxilofacial: princípios básicos e aplicações - revisão de literatura. Rev. Bras. Cir. Plást. v3, p234239, 2007.

(4) RIBEIRO N. L., Titânio e suas ligas como biomateriais em substituições de tecidos duros. Trabalho de Conclusão de Curso - Centro Federal de Educação Tecnológica de Minas Gerais, Belo Horizonte, 2014

(5) RODRIGUES, M.; DA CRUZ N. C.; ROCHA J. A. F.; SA R. C. L.; BOCK E. G. P. Surface roughness of biomaterials and process parameters of titanium dioxide gritblasting for productivity enhancement. The Academic Society Journal (TASJ), v. 3,n.2, p. 169-176, 2019.

(6) LANDUCI M. C. Caracterização das propriedades mecânicas de biomateriais metálicas. 2016. Dissertação (Pós-Graduação em Engenharia Mecânica) - Faculdade Estadual de Bauru, Bauru,2016.

(7) PASCHOAL, André Luís. Avaliação da Resistência à corrosão em meio fisiológico de metais revestidos com nitreto de titânio. 1998. Dissertação (Mestrado em Ciências e Engenharia de Materiais) - Universidade de São Paulo, São Paulo, 1998.

(8) SOUZA, C. M. P.; SILVA JUNIOR, W. C.; MILITAO, V. A.; CIOCA, V. V. Análise da biocompatibilidade de parafusos de fixação de próteses de fêmur em liga de titânio ASTM F136. The Academic Society Journal (TASJ) , v. 2, p. 103-109, 2018.

(9) MALISKA, Ana Maria. Microscopia eletrônica de Varredura.

(10) CALLISTER, William D.; RETHWISCH, David G. Materials Science and engineering: an introduction. New York: Wiley, 2012.

(11) ASTM F136 - 13 Standard Specification for Wrought Titanium-6Aluminum4Vanadium ELI (Extra Low Interstitial) Alloy for Surgical Implant Applications (UNS R56401). 